\title{
Rancang Bangun Game Berhitung Spaceship dengan Pengendali Suara Menggunakan Speech Recognition Plugin pada Unity
}

\author{
Hans Alfon Ericksoon, Imam Kuswardayan dan Dr. Eng Nanik Suciati \\ Jurusan Teknik Informatika, Fakultas Teknologi Informasi, Institut Teknologi Sepuluh Nopember (ITS) \\ Jl. Arief Rahman Hakim, Surabaya 60111 Indonesia \\ e-mail: imam@if.its.ac.id
}

\begin{abstract}
Abstrak-Berhitung merupakan salah satu bagian dari modal awal dalam menjalani proses pendidikan. Dasar-dasar pembelajaran berhitung umumnya diberikan kepada siswa SD kelas 1 dan 2. Namun, anak-anak SD kebanyakan lebih memilih bermain ketika pulang bersekolah dari pada melatih kemampuan berhitungnya. Dengan teknologi yang ada saat ini, pelatihan kemampuan berhitung dapat dibuat lebih menarik, interaktif dan dapat dilakukan dimana saja. Pada Tugas Akhir ini dikembangkan suatu game berhitung Spaceship yang berbasis android dengan pengendali suara menggunakan Speech recognition Plugin. Tujuan dari pembuatan Tugas Akhir ini adalah membuat sebuah game yang dapat digunakan sebagai sarana alternatif untuk mengasah kemampuan berhitung anakanak. Penyusunan materi yang digunakan dalam game ini mengikuti panduan beberapa buku matematika untuk anak-anak SD yang diterbitkan oleh Departemen Pendidikan Nasional sebagai referensi sehingga anak-anak dapat melatih kemampuan berhitungnya sesuai dengan kurikulum di sekolah. Game ini menjadi interaktif dengan diterapkannya fitur Speech recognition sehingga semakin menarik minat anak-anak.
\end{abstract}

Kata Kunci-Android, Permainan, Spaceship

\section{PENDAHULUAN}

$\mathrm{S}$ MARTPHONE berbasis Android sangat digemari di masyarakat, tidak terkecuali anak-anak. Kebiasaan dan budaya anak-anak saat ini telah berubah. Sebagian besar dari mereka akan lebih memilih menghabiskan waktu menggunakan smartphone. Baik itu milik mereka sendiri atau milik orang tua mereka. Hal ini mengakibatkan kurangnya minat anak untuk belajar khususnya belajar berhitung.

Hal ini tentunya mengakibatkan timbulnya kekhawatiran pada diri orang tua. Baik itu khawatir akan jenis game yang dimainkan oleh anak, maupun khawatir apabila anak kecanduan bermain game sehingga dapat mengakibatkan semangat belajar anak menjadi menurun dan kemampuan dalam pelajaran berkurang, khususnya dalam pelajaran berhitung. Untuk mengurangi dampak buruk dari hal tersebut, dibuat sebuah game Spaceship dengan tema edukasi pada smartphone yang berbasis android. Dengan adanya game dengan edukasi ini, diharapkan agar anak-anak tetap dapat mengasah kemampuannya dalam hal pelajaran selama bermain game.

Game Spaceship ini mengimplementasikan operasi perhitungan dasar seperti penjumlahan, pengurangan, perkalian dan pembagian. Sehingga anak-anak yang memainkan game ini dapat mengasah kemampuan berhitung mereka. Dengan adanya media pembelajaran melalui game pada smartphone ini, maka anak-anak diharapkan dapat selalu megasah kemampuan berhitung mereka.

\section{TINJAUAN PUSTAKA}

\section{A. Sistem Operasi Android}

Sistem operasi Android adalah sistem operasi berbasis Linux yang dirancang untuk perangkat seluler layar sentuh. Android memungkinkan pengembang untuk memodifikasi secara bebas dan didistribusikan oleh para pembuat perangkat, operator nirkabel, dan pengembang aplikasi [1]. Android memungkinkan pengguna untuk memasang aplikasi baik yang didapat dari Google Play, Amazon Appstore, ataupun dengan mengunduh dan menginstal file executable untuk sistem operasi Android yang memiliki tipe apk. Berikut adalah beberapa sistem operasi Android:

1. Android versi 3.0 (Android HoneyComb).

2. Android versi 4.0 (Android Ice Cream Sandwich).

3. Android versi 4.1 (Android Jelly Bean).

4. Android versi 4.2 (Android KitKat).

Beberapa sistem operasi android mendukung kinerja seperti multitasking, open source, dan integrasi mudah dengan produkproduk Google. Pengembangan aplikasi android membutuhkan Software Development Kit (SDK) Android, pada SDK tersebut versi yang digunakan adalah android dengan sistem operasi Android versi 2.3.3. Versi tersebut tergolong stabil untuk diterapkan pada aplikasi yang dikembangkan.

\section{B. Unity $3 D$}

Unity 3D atau Unity adalah perangkat lunak game engine untuk membangun permainan 3 Dimensi (3D). Game engine adalah alat yang berada dibalik layar sebuah aplikasi/game dari artwork sampai perhitungan matematika dan rendering. Unity 3D berperan dalam menciptakan obyek maya 3D dan proses rendering grafis sama seperti yang dilakukan pada lingkungan antarmuka Unity 3D

Unity merupakan suatu game development ecosystem yang mampu digunakan untuk membuat game dalam berbagai macam platform baik console, desktop, dan mobile. Bahasa pemrograman utama Unity adalah C\# dengan IDE Mono Develop [2].

Unity 3D berbasis cross-platform, sehingga pengembang dapat membuat game yang dapat dimainkan pada perangkat komputer, ponsel pintar android, web games (memerlukan plugin unity web player), iPhone, PS3, dan bahkan X-BOX. 
Unity3D menyediakan software free dan pro, untuk versi gratis Unity menyediakan fitur pengembangan game berbasis windows, standlone mac dan web. Sedangkan untuk Unity Pro terdapat fitur yang lebih komplit dibandingkan dengan Unity Free seperti efek bayangan pada objek dan efek water yang lebih memukau.

Dalam unity disediakan berbagai pilihan bahasa pemrograman untuk mengembangkan game, antara lain JavaScript, C Sharp (C\#), dan BooScript. Dalam penelitian ini penulis menggunakan bahasa pemrograman $\mathrm{C}$ Sharp (C\#) untuk mengembangkan aplikasi.

\section{Speech recognition}

Speech recognition yang juga dikenal dengan Automatic Speech recognition (ASR) merupakan teknologi yang diterapkan pada perangkat lunak untuk menerima input berupa kata yang diucapkan. Teknologi ini memungkinkan suatu perangkat untuk mengenali dan memahami kata-kata yang diucapkan dengan cara digitalisasi kata dan mencocokkan sinyal digital tersebut dengan suatu pola tertentu yang tersimpan dalam suatu perangkat. Kata-kata yang diucapkan diubah menjadi sekumpulan angka yang kemudian disesuaikan dengan kode-kode tertentu untuk mengidentifikasi kata-kata tersebut [4]. Speech recognition yang digunakan dalam game berhitung Spaceship merupakan sebuah plugin dari kakas unity. Dimana dalam penggunaannya, Speech recognition akan mengirimkan suara yang diterima ke server untuk diproses menjadi teks.

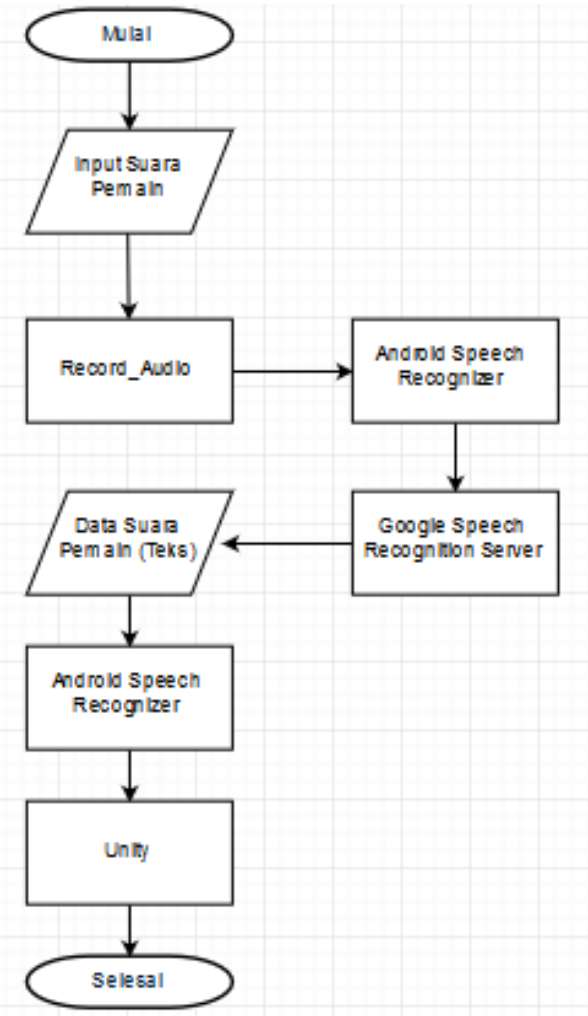

Gambar 1 Alur Speech recognition Plugin Mengubah Suara Menjadi Teks

Untuk menggunakan plugin ini, game yang dibuat harus memiliki izin merekam suara dan izin menggunakan koneksi internet pada Android Manifest. Plugin ini juga memerlukan banyak tenaga baterai dan bandwidth jika digunakan dalam waktu yang lama. Untuk arsitektur alur pengubahan suara menjadi teks oleh Speech recognition dapat dilihat pada Gambar 1.

\section{Bahasa Pemrograman C\#}

Telah kita ketahui bersama bahwa Microsoft memiliki banyak sekali bahasa pemrograman seperti Visual Basic.NET, Visual Basic, Visual C++, Visual C\#.NET, serta visual lain-lain yang dapat anda cari hingga kita bingung memilih mana yang terbaik. Untuk saya pribadi, mungkin akan lebih menekuni C\#.NET ini ketimbang bahasa pemrograman lain seperti Visual Basic maupun $\mathrm{C}++$.

C\# merupakan sebuah bahasa pemrograman yang berorientasi objek yang dikembangkan oleh Microsoft sebagai bagian dari inisiatif kerangka .NET Framework. Bahasa pemrograman ini dibuat berbasiskan bahasa $\mathrm{C}++$ yang telah dipengaruhi oleh aspek-aspek ataupun fitur bahasa yang terdapat pada bahasa-bahasa pemrograman lainnya seperti Java, Delphi, Visual Basic, dan lain-lain) dengan beberapa penyederhanaan. Menurut standar ECMA-334 C\# Language Specification, nama C\# terdiri atas sebuah huruf Latin C (U+0043) yang diikuti oleh tanda pagar yang menandakan angka \# (U+0023). Tanda pagar \# yang digunakan memang bukan tanda kres dalam seni musik (U+266F keyboard standar [3].

\section{ANALISIS DAN PERANCANGAN}

\section{A. Domain Permasalahan}

Berhitung merupakan salah satu modal dasar yang sangat penting di dalam dunia pendidikan. Tetapi sebagian besar anakanak lebih memilih bermain dari pada melatih kemampuan berhitung mereka. Untuk itu, sarana alternatif untuk latihan berhitung sangat penting bagi anak-anak.

Permasalahan utama yang diangkat dalam pembuatan Tugas Akhir ini adalah bagaimana meningkatkan minat anak untuk melatih kemampuan berhitung mereka. Dengan adanya sarana alternatif yang menarik dan interaktif, diharapkan anak-anak menjadi lebih tertarik untuk melatih kemampuan berhitungnya.

Sarana alternatif yang digunakan adalah dengan membuat sebuah game berbasis Android dengan menerapkan materi berhitung di dalam game yang dibuat. Pembuatan game pada perangkat Android bertujuan untuk mempermudah anak-anak dalam mengasah kemampuan berhitung, selain itu perangkat Android tergolong mudah untuk dibawa sehingga anak-anak dapat menggunakannya di mana pun dan saat ini hampir setiap rumah memiliki perangkat dengan sistem operasi Android.

\section{B. Deskripsi Umum}

Berdasarkan permasalahan yang ada pada pembahasan domain permasalahan, solusi aplikasi yang akan ditawarkan adalah pembuatan game berhitung Spaceship dengan menggunakan Speech recognition plugin pada unity sebagai pengendali suara. Game yang dibangun bertujuan sebagai sarana alternatif untuk meningkatkan minat anak-anak dalam mengasah kemampuan berhitung. Diharapkan agar anak-anak mendapatkan sarana alternatif yang menarik dan interaktif yang tidak menyebabkan mental hectic bagi anak-anak yang menggunakannya. Materi berhitung yang diterapkan pada game ini merupakan materi yang berasal dari buku matematika SD 
yang diterbitkan oleh Departemen Pendidikan Nasional yang sesuai dengan kurikulum, sehingga tidak memberikan beban yang berlebih pada anak dalam memahami soal-soal yang dikerjakan.

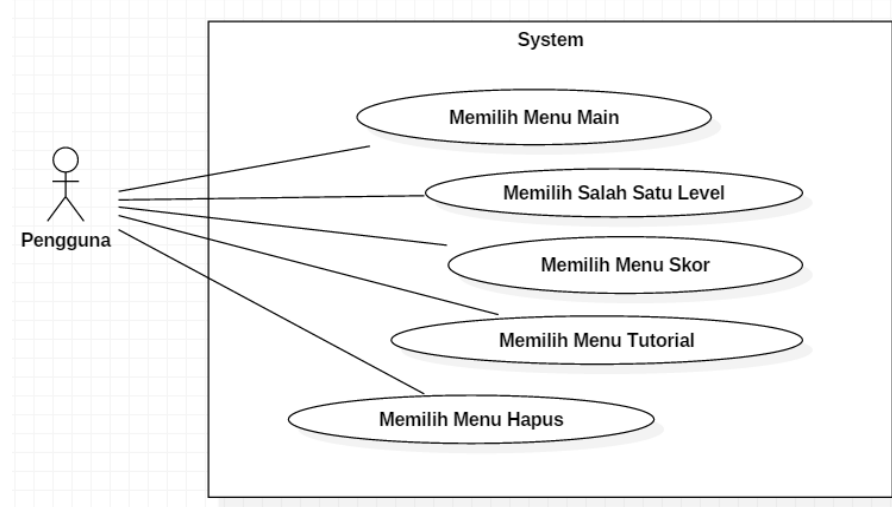

Gambar 2 Diagram kasus penggunaan

Tabel 1.

Materi yang Diterapkan Tiap Level

\begin{tabular}{|c|c|c|}
\hline Level & $\begin{array}{c}\text { Operasi perhitungan yang } \\
\text { digunakan(jumlah) }\end{array}$ & $\begin{array}{c}\text { Bilangan yang } \\
\text { digunakan }\end{array}$ \\
\hline Level 1 & - Penjumlahan (3) & - 0 sampai 9 \\
\hline Level 2 & - Pengurangan (3) & - 0 sampai 9 \\
\hline Level 3 & $\begin{array}{l}\text { - Penjumlahan (2) } \\
\text { - Pengurangan (1) }\end{array}$ & $\begin{array}{l}\text { - } 0 \text { sampai } 9 \\
\text { - } 0 \text { sampai } 9\end{array}$ \\
\hline Level 4 & $\begin{array}{l}\text { - Penjumlahan (1) } \\
\text { - Pengurangan (2) }\end{array}$ & $\begin{array}{l}\text { - } 0 \text { sampai } 50 \\
\text { - } 0 \text { sampai } 50\end{array}$ \\
\hline $\begin{array}{l}\text { Level } 5 \\
\text { Level } 6 \\
\text { Level } 7 \\
\text { Level } 8\end{array}$ & $\begin{array}{l}\text { - Perkalian (3) } \\
\text { - Pembagian (3) } \\
\text { - Perkalian (3) } \\
\text { - Pembagian (3) }\end{array}$ & $\begin{array}{l}\text { - } 1 \text { sampai } 3 \\
-1 \text { sampai } 20 \\
-1 \text { sampai } 9 \\
-1 \text { sampai } 50\end{array}$ \\
\hline Level 9 & $\begin{array}{l}\text { - Perkalian (1) } \\
\text { - Pembagian (2) }\end{array}$ & $\begin{array}{l}-1 \text { sampai } 9 \\
-1 \text { sampai } 50\end{array}$ \\
\hline
\end{tabular}

\section{Aktor}

Aktor mendefinisikan entitas-entitas yang terlibat dan berinteraksi langsung dengan sistem. Entitas ini bisa berupa manusia maupun sistem atau perangkat lunak yang lain. Aktor yang terdapat pada sistem ini hanya memiliki sebuah peran yaitu sebagai pemain. Pemain adalah orang yang memainkan game ini.

\section{Kasus Penggunaan}

Berdasarkan analisis spesifikasi kebutuhan fungsional dan analisis aktor dari sistem dibuat kasus penggunaan sistem. Kasus-kasus penggunaan dalam sistem ini akan dijelaskan secara rinci pada subbab ini. Kasus penggunaan digambarkan dalam sebuah diagram kasus penggunaan. Diagram kasus penggunaan dapat dilihat pada Gambar 2.

\section{E. Perancangan Aturan Main, Skenario dan Level}

Aturan main dan skenario pada game ini merupakan adaptasi dari game Spaceshooter namun dengan beberapa modifikasi. Aturan main dan skenarionya adalah pemain harus menembak meteor yang mengarah ke pesawat. Namun pada game ini, pemain menembak dengan cara yang berbeda yaitu dengan menjawab operasi perhitungan yang terdapat di bawah masing-masing pesawat. Hal ini dimaksudkan agar terkandung unsur edukasi di dalam game ini. Untuk tingkat kesulitan levelnya semakin tinggi level maka bilangan yang digunakan di dalam operasi perhitungan akan semakin besar. Selain itu, operasi perhitungan yang diterapkan juga akan berganti seiring dengan bertambahnya level.

\section{F. Perancangan Penyisipan Operasi Perhitungan}

Operasi perhitungan disisipkan pada bagian permainan utama. Dimana saat pemain akan menembak meteor maka pemain harus menjawab hasil dari sebuah operasi perhitungan. Apabila pemain menjawab dengan benar, maka pesawat akan menembak dan pesawat tidak akan menembak apabila jawaban pemain salah. Untuk materi perhitungan yang diterapakan di dalam game ini dapat dilihat pada Tabel 1.

\section{G. Rancangan Teknologi Speech recognition}

Speech recognition yang digunakan merupakan sebuah Speech recognition Plugin pada kakas Unity. Fungsi Speech recognition akan digunakan pada pesawat yang akan menembak meteor. Speech recognition akan menerima jawaban pemain yang berupa suara dan akan mengubahnya menjadi teks untuk dicocokkan dengan jawaban yang benar dari operasi perhitungan. Untuk menggunakan plugin ini, dibutuhkan izin penggunaan mikrofon pada smartphone untuk record_audio dan izin penggunaan internet untuk mengirimkan data suara ke server untuk diubah menjadi teks.

\section{PENGUJIAN}

Pengujian aplikasi meliputi uji coba fitur buka/tutup level, mengecek kebenaran jawaban pemain dan uji coba menampilkan skor tertinggi. Pengujian fitur buka/tutup level berfungsi untuk mengetahui keberhasilan sistem dalam membuka level setelah pemain menyelesaikan level sebelumnya dan tetap menutup level jika level sebelumnya belum terselesaikan. Untuk hasil uji coba ini dapat dilihat pada Tabel 2.

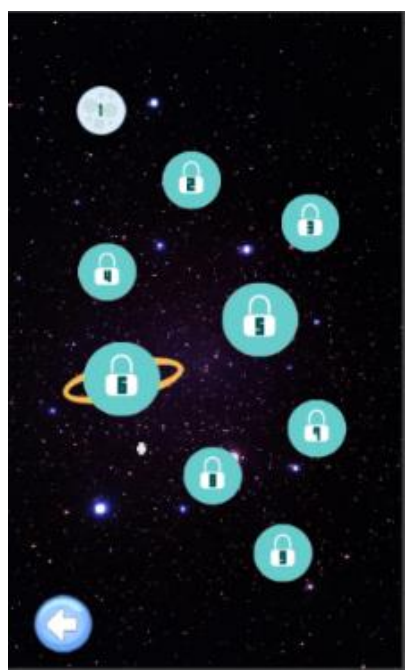

Gambar 3 Tampilan Level Belum Diselesaikan 


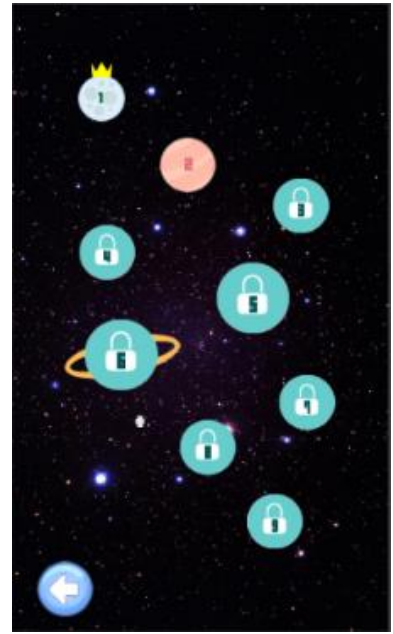

Gambar 4 Tampilan Setelah Level Diselesaikan

Tabel 2

Hasil Uji Coba Buka/Tutup Leve

\begin{tabular}{|c|c|}
\hline ID & UJ-P-1 \\
\hline Nama & Uji Coba Fitur Buka/Tutup Level \\
\hline Tujuan Uji Coba & $\begin{array}{l}\text { Menguji apakah sistem dapat membuka dan } \\
\text { menutup level dengan bebar serta memberi } \\
\text { mahkota pada level yang sudah diselesaikan }\end{array}$ \\
\hline Kondisi awal & Pengguna berada pada halaman Menu Utama \\
\hline Skenario 1 & $\begin{array}{ll}\text { - } & \text { Pemain masuk ke menu level } \\
\text { - } & \text { Sistem menampilkan pilihan level } \\
& \text { Pemain memilih level yang terbuka } \\
\text { - } & \text { Pemain menyelesaikan level }\end{array}$ \\
\hline Skenario 2 & $\begin{array}{ll}\text { - } & \text { Pemain masuk ke menu level } \\
\text { - } & \text { Sistem menampilkan pilihan level } \\
\text { - } & \text { Pemain memilih level yang terbuka } \\
\text { - } & \text { Pemain tidak menyelesaikan level }\end{array}$ \\
\hline $\begin{array}{l}\text { Keluaran yang } \\
\text { diharapkan }\end{array}$ & $\begin{array}{l}\text { Sistem dapat membuka level berikutnya } \\
\text { apabila level diselesaikan dan memberi } \\
\text { mahkota pada level yang telah diselesaikan } \\
\text { - Sistem tidak membuka level berikutnya } \\
\text { ketika level tidak diselesaikan }\end{array}$ \\
\hline Hasil Uji Coba & - Berhasil \\
\hline Kondisi Akhir & $\begin{array}{l}\text { - Sistem membuka level berikutnya dan } \\
\text { memberi mahkota pada level yang telah } \\
\text { diselesaikan } \\
\text { - }\end{array}$ \\
\hline
\end{tabular}

Pada uji coba yang dilakukan, sistem dapat menjalankan fitur buka/tutup level dengan baik. Tampilan ketika pemain belum menyelesaikan sebuah level dapat dilihat pada Gambar 3 dan tampilan ketika pemain sudah menyelesaikan sebuah level dapat dilihat pada Gambar 4.

Uji coba mengecek kebenaran jawaban pemain merupakan pengujian game dalam menerima jawaban berupa suara dan mencocokkan dengan jawaban yang benar dari operasi perhitungan yang ditampilkan dalam game. Hasil pengujian secara lengkap dapat dilihat pada Tabel 3. Pada Uji coba yang dilakukan, sistem dapat menjalankan proses mengubah suara menjadi teks dengan benar dan sistem dapat mencocokkan jawaban dengan baik. Tampilan yang didapat ketika pemain menyebutkan jawab dengan benar dapat dilihat pada Gambar 5.

Tabel 3

Hasil Uji Coba Mengecek Kebenaran Jawaban Pemain

\begin{tabular}{ll}
\hline \hline ID & UJ-P-2 \\
\hline Nama & Uji Coba Mengecek Kebenaran Jawaban Pemain \\
\hline \hline
\end{tabular}

\begin{tabular}{|c|c|}
\hline Tujuan Uji Coba & $\begin{array}{l}\text { Menguji apakah sistem dapat menerima jawaban } \\
\text { pemain yang berupa suara dan mencocokkan } \\
\text { dengan jawaban benar dari sebuah operasi } \\
\text { perhitungan yang ditampilkan }\end{array}$ \\
\hline Kondisi awal & Pengguna berada pada game berhitung Spaceship \\
\hline Skenario 1 & $\begin{array}{l}\text { - } \quad \text { Sistem menampilkan game berhitung } \\
\text { Spaceship } \\
\text { - } \quad \text { Sistem memberi tanda yang berarti sistem } \\
\text { siap untuk menerima masukan berupa suara } \\
\text { - } \quad \text { Pemain menyebutkan jawaban benar dari } \\
\text { operasi perhitungan }\end{array}$ \\
\hline Skenario 2 & $\begin{array}{l}\text { - } \quad \text { Sistem menampilkan game berhitung } \\
\text { Spaceship } \\
\text { - } \quad \text { Sistem memberi tanda yang berarti sistem } \\
\text { siap untuk menerima masukan berupa suara } \\
\text { - } \quad \begin{array}{l}\text { Pemain menyebutkan jawaban salah dari } \\
\text { operasi perhitungan }\end{array}\end{array}$ \\
\hline Masukan & $\begin{array}{l}\text { Pemain mengucapkan jawaban dari operasi } \\
\text { perhitungan yang ditampilkan }\end{array}$ \\
\hline $\begin{array}{l}\text { Keluaran yang } \\
\text { diharapkan }\end{array}$ & $\begin{array}{l}\text { - Pesawat akan menembak jika jawaban pemain } \\
\text { benar dan angka dari operasi perhitungan } \\
\text { akan berganti } \\
\text { - Pesawat tidak akan menembak jika jawaban } \\
\text { pemain salah dan angka dari operasi } \\
\text { perhitungan tidak berganti }\end{array}$ \\
\hline Hasil Uji Coba & Berhasil \\
\hline Kondisi Akhir & $\begin{array}{l}\text { - Ketika pemain menyebutkan jawaban dengan } \\
\text { benar pesawat menembak dan angka dari } \\
\text { operasi perhitungan berganti } \\
\text { Ketika pemain menyebutkan jawaban dengan } \\
\text { salah pesawat tidak menembak dan angka } \\
\text { dari operasi perhitungan tidak berganti }\end{array}$ \\
\hline
\end{tabular}

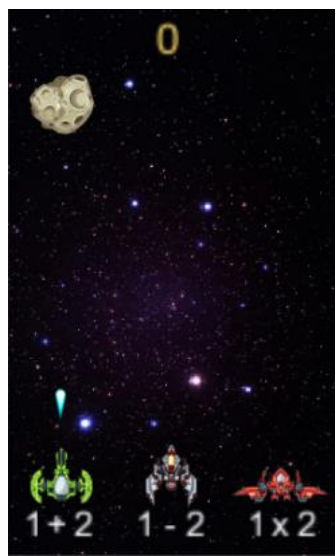

Gambar 5 Pemain Menyebutkan Jawaban dengan Benar

Angka dari operasi perhitungan yang berada dibawah pesawat yang sedang menembak akan berganti bersamaan dengan pesawat menembak, sehingga jika pemain ingin menembak menggunakan pesawat ini lagi maka pemain harus menjawab operasi perhitungan yang baru.

Uji coba menampilkan skor tertinggi adalah pngujian fungsi sistem dalam menyimpan skor tertinggi. Uji coba ini bertujuan untuk mengetahui apakah sistem dapat menyimpan dan mengurutkan skor tertinggi dengan benar. Untuk Hasil pengujian selengkapnya dapat dilihat pada Tabel 4.

Tabel 4

Hasil Uji Coba Menampilkan Skor Tertinggi

\begin{tabular}{ll}
\hline \hline ID & UJ-P-3 \\
\hline Nama & Uji Coba Menampilkan Skor Tertinggi \\
\hline \hline
\end{tabular}




\begin{tabular}{ll}
\hline \hline Tujuan Uji Coba & $\begin{array}{l}\text { Menguji apakah sistem dapat menyimpan dan } \\
\text { menampilkan skor tertinggi dengan benar }\end{array}$ \\
Kondisi awal & Pengguna berada pada menu utama \\
Skenario 1 & $-\quad$ Sistem menampilkan skor tertinggi yang \\
& telah tersimpan \\
& $-\quad$ Pemain memainkan game sebanyak 3 kali \\
& dan berakhir dengan 3 skor yang berbeda \\
& Pemain melihat papan skor \\
Masukan & $\begin{array}{l}\text { Pemain mengakhiri permainan dengan skor } \\
\text { Keluaran yang }\end{array}$ \\
diharapkan & $\begin{array}{l}\text { Sistem akan menampilkan 3 skor tertinggi yang } \\
\text { telah tersimpan dengan mengurutkan dari skor }\end{array}$ \\
Hasil Uji Coba & yang paling besar \\
Kondisi Akhir & Berhasil \\
& Sistem menampilkan skor tertinggi dengan \\
& urutan yang benar \\
\hline \hline
\end{tabular}

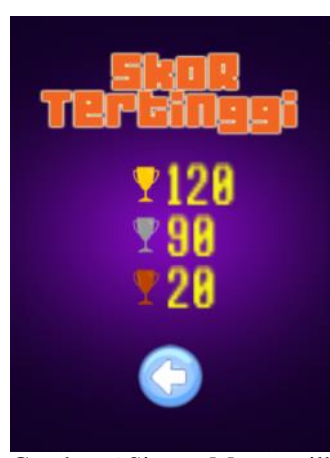

Gambar 6 Sistem Menampilkan Urutan Skor Tertinggi dengan Benar

Saat pemain mengakhiri permainan baik dengan menyelesaikan level ataupun game over maka sistem akan menyimpan skor. Apabila skor yang diperoleh lebih besar dari salah satu 3 skor tertinggi, maka sistem akan memasukkan skor yang di peroleh ke deretan skor tertinggi. Tampilan yang didapatkan ketika pemain melihat papan skor dapat dilihat pada Gambar 6.

\section{KESIMPULAN}

Speech recognition dapat berjalan dengan baik dalam game Spaceship tetapi masih membutuhkan koneksi internet yang stabil dalam penggunaannya. Pada lingkungan dengan tingkat kebisingan yang rendah Speech recognition dapat berjalan dengan baik, tetapi pada lingkungan dengan tingkat kebisingan yang sedang dan tinggi kinerja Speech recognition sedikit terganggu. Pengimplementaasian operasi perhitungan, pencocokan jawaban oleh sistem dan sistem buka/tutup level sudah dapat berjalan dengan baik.

Adapun pemain perlu untuk melihat tutorial terlebih dahulu sebelum memainkan game ini agar tidak mengalami kesulitan dalam memainkannya dan proses pembelajaran tentunya dilakukan secara rutin agar materi yang diberikan dapat dipahami dan dimengerti secara menyeluruh.

\section{DAFTAR PUSTAKA}

[1] Jerry hildenbrand, What is Android?, 16 Mei 2015. [Online]. Tersedia: http://www.androidcentral.com/what-android [Diakses pada 21 Maret 2016].

[2] Unity, "Game engine, tools and multi platfrom," Unity, [Online]. Tersedia: http://unity3d.com/unity. [Diakses pada 22 Februari 2016].
[3] Microsoft, Introduction to the C\# Language and the .NET Framework, 24 Maret 2015. [Online]. Tersedia: http://www.visualstudio.com/. [Diakses pada 4 Maret 2016].

[4] Rasimah Abuhari, Speech recognition, 21 Januari 2014. [Online]. Tersedia: http://www.academia.edu/17407888/speech_recognition. [Diakses pada 22 Februari 2016]. 